\title{
Article \\ Relationship of Obesity with Lifestyle and Comorbidities in Public School Teachers-A Cross-Sectional Study
}

\author{
William R. Tebar ${ }^{1}\left(\right.$ D, Fernanda C. S. Gil ${ }^{2}$, Leandro D. Delfino ${ }^{2}$, Jefferson M. Souza ${ }^{2}$, Jorge Mota ${ }^{3}(\mathbb{D}$ \\ and Diego G. D. Christofaro ${ }^{2, *}$ \\ 1 Center of Clinical and Epidemiological Research, University Hospital, University of São Paulo, \\ São Paulo 05508-000, Brazil; william.tebar@hotmail.com \\ 2 Faculty of Science and Technology, Sao Paulo State University, Presidente Prudente 19060-900, Brazil; \\ feernanda_gil@hotmail.com (F.C.S.G.); ledragueta@hotmail.com (L.D.D.); \\ jefferson.msouza@hotmail.com (J.M.S.) \\ 3 Research Center in Physical Activity, Health and Leisure (CIAFEL), Faculty of Sports, University of \\ Porto (FADEUP) and Laboratory for Integrative and Translational Research in Population Health (ITR), \\ 4200-450 Porto, Portugal; jmota@fade.up.pt \\ * Correspondence: diegochristofaro@yahoo.com.br; Tel.: +55-18-3229-5388
}

Citation: Tebar, W.R.; Gil, F.C.S.; Delfino, L.D.; Souza, J.M.; Mota, J.; Christofaro, D.G.D. Relationship of Obesity with Lifestyle and Comorbidities in Public School Teachers-A Cross-Sectional Study. Obesities 2022, 2, 52-63. https:// doi.org/10.3390/obesities2010006

Academic Editor: Bruno Guigas

Received: 28 December 2021

Accepted: 17 January 2022

Published: 1 February 2022

Publisher's Note: MDPI stays neutral with regard to jurisdictional claims in published maps and institutional affiliations.

Copyright: (C) 2022 by the authors. Licensee MDPI, Basel, Switzerland. This article is an open access article distributed under the terms and conditions of the Creative Commons Attribution (CC BY) license (https:// creativecommons.org/licenses/by/ $4.0 /)$.

\begin{abstract}
Obesity is one of the major public health burdens, and is a global pandemic that has been associated with lifestyle habits and comorbidities in the general population. Teachers comprise a wide category of workers with unestablished factors associated with obesity. This cross-sectional epidemiological study analyzed the association of obesity, defined by body mass index $\geq 30 \mathrm{~kg} / \mathrm{m}^{2}$, with work-related factors (years in the profession, hours worked weekly), lifestyle (sports practice, active commuting, TV viewing, smoking, alcohol consumption), and comorbidities (hypertension, diabetes, dyslipidemia) in a sample of 246 public school teachers. An elevated prevalence of obesity was observed in the sample (30.1\%), which was associated with $\geq 2 \mathrm{~h} /$ day of TV viewing (OR: 2.10, $p=0.025$ ) and hypertension (OR: $2.62, p=0.010)$, whereas it was inversely associated with frequent active commuting by walking or cycling (OR: $0.22, p=0.007$ ), even after multiple adjustments. No association was observed between obesity and work-related factors. Actions focused on promoting active commuting while limiting TV time could be important strategies for facing the elevated prevalence of obesity in public school teachers. However, the analysis of longitudinal data and investigation of obesogenic determinants are still needed.
\end{abstract}

Keywords: body mass index; physical activity; screen time; active commuting; chronic diseases

\section{Introduction}

Obesity is one of the major burdens on public health, being considered a global pandemic [1]. The worldwide prevalence of obesity nearly tripled in the last four decades, reaching $13 \%$ of the adult population [2]. Obesity has been associated with several physical and mental health problems, such as hypertension, diabetes and dyslipidemia [3], different types of cancer [4], anxiety and depression symptoms [5], body dissatisfaction [6], and also with higher all-cause mortality [7].

Obesity is characterized by an abnormal accumulation of body fat, being a complex disease with an etiology associated with multiple factors [8]. Epidemiologically, adults who present a body mass index $\geq 30 \mathrm{~kg} / \mathrm{m}^{2}$ are defined as obese [9]. The body fat accumulation occurs when the person fails to match energy intake with energy expenditure over time, resulting in weight gain [10]. Unhealthy dietary habits are the main source of excessive energy intake, which may be counterpoised by a low daily energy expenditure through lifestyle habits, in a positive cycle of caloric storage [11].

Teachers comprise a wide category of workers who have specific environmental and psychological exposures, which may affect their jobs and the people involved with their 
occupation [12]. Most of the teachers reported excessive work hours, which has been associated with psychological distress, lower time for leisure activities, and poor sleep quality [13]. Although it has been reported that teachers with lower body mass index presented a more lifestyle habits [14], higher than $50 \%$ of teachers had lower physical activity levels and high levels of TV viewing, which was associated with poor sleep quality [15] and corresponds to an obesogenic exposure due to prolonged lower energy expenditure condition during the day. Moreover, teachers with poor sleep quality were more likely to have obesity, mental disorders, and chronic pain [15], which could be important limitation factors for a healthy and physically active lifestyle. In this sense, the excessive workload and its consequences as well as lower adherence to an active lifestyle may lead teachers to be more likely to have obesity than other populations. However, it is still not established whether these factors could be associated with obesity in public school teachers, since policies and programs in the school environment have been most widely focused on students [16], and studies involving teachers in the school environment are scarce and unspecific [17].

In this sense, this study aimed to analyze the association of obesity with work-related factors, lifestyle habits, and comorbidities among public school teachers.

\section{Methods}

\subsection{Study Design}

This is an observational study with a cross-sectional design, conducted in the city of Presidente Prudente, located in the southeastern and more industrialized region of Brazil. The city has a population of 227,072 inhabitants, and a Human Development Index of 0.806 (where zero is low and 1 is high). According to the city's Educational Board, there are 23 public schools, with 650 teachers in total. The research was approved by the Research Ethics Committee from Sao Paulo State University, process number 72191717.9.0000.5402.

\subsection{Sample Process and Data Collection}

The sample size calculation was based on an overall prevalence of $50 \%$ of the outcome adopted in epidemiological studies, when there is an unknown prevalence or multiple outcomes for a finite population [18]. A tolerable error of 5\%, a 95\% confidence interval, and a power of study of $80 \%$ were also considered for the population of 650 public school teachers, resulting in a minimum sample size of 242 participants.

For the sample selection, the schools were stratified according to the geographical regions of the city (North, South, East, West, and Central). Initially, two schools were selected to be visited in each region. The manager of each school, from whom the respective authorization was requested, was contacted and informed about the realization of this research. In the case of a negative reply, another school was selected in the same region and successively. If the minimum sample was not reached in the visited schools, another school would be selected until the sample size was reached or when all public schools in the city were visited. In the authorized schools, all of the teachers were invited to participate, where each one would decide to participate in the study or not. At the end of the sampling process, 10 schools did not authorize the research and all of the remaining 13 schools were visited, comprising the total of the public schools in the city.

The data collection was performed in a separate room previously granted by the school, in the horary of the collective pedagogical work (when teachers come together to plan their work activities). The following were considered as inclusion criteria for the study: (i) be a practicing teacher in the public school system of the city; and (ii) agree to participate in the study by means of a signed informed consent form.

\subsection{Obesity Assessment}

Obesity was defined according to the cutoff point of a body mass index $\geq 30 \mathrm{~kg} / \mathrm{m}^{2}$, proposed by the World Health Organization [19]. Objective anthropometric measurements of body mass and height were collected in a previously granted room in the school, with 
the body mass index calculated by the division of the body mass by the height squared $\left(\mathrm{BMI}=\mathrm{kg} / \mathrm{m}^{2}\right)$. Body mass was assessed with a WISO ${ }^{\circledR}$ digital scale, with a precision of $0.1 \mathrm{~kg}$ and a maximum capacity of $180 \mathrm{~kg}$, while the height was assessed with a portable wall-fixed Sanny ${ }^{\circledR}$ stadiometer, with a maximum capacity of $2.20 \mathrm{~m}$ and precision within $0.1 \mathrm{~cm}$. For this evaluation, participants were barefoot, wearing light clothes, and not carrying other personal belongings such as coats and purses.

\subsection{Work-Related Factors}

Information about the quantity of hours worked per week and the number of years in this occupation were collected in the sample. To obtain this information, the following questions were asked and the answers computed: "How many hours do you work per week in your profession?" and "How long have you been working in this profession?" For the statistical analysis, hours worked per week were categorized into four categories: " $20 \mathrm{~h}$ or less"; "from 21 to $40 \mathrm{~h}$ "; and "more than $40 \mathrm{~h}$ ". The total time working as a teacher was categorized as " 10 years or less", "from 11 to 20 years", and "more than 20 years".

\subsection{Physical Activity Measurements}

The Habitual Physical Activity questionnaire by Baecke et al. [20] was used to assess the practice of sports or physical exercise at leisure and the active commuting of the sample. This instrument was previously validated against gold-standard methods [21] and an accelerometer [22], being reliable in the Brazilian adult population [23].

Participants were asked how frequently they practiced sports or physical exercises at leisure time, by the question: "During leisure hours, I practiced sports or physical exercises: i. Never; ii. seldom; iii. sometimes; iv. often; v. very often".

The active commuting by walking or cycling was assessed with the questions: "How frequently do you walk or cycle as a form of commuting?" Responses were: i. Never; ii. seldom; iii. sometimes; iv. often; v. very often.

\subsection{Barriers for Physical Activity}

The Barriers in Physical Activity and Exercise Participation questionnaire [24] was administered in the sample. This instrument presented good internal consistency (Cronbach's alpha $=0.92)$ and good test-retest correlations $(r=0.74-0.95)$ among adults $45-65$ years of age [24]. Participants reported which were the main barriers to physical activity, according to the options: 1. Laziness, tiredness or discouragement; 2. Lack of time; 3. Lack of company; 4. Lack of money; 5. Lack of motivation; 6 . Afraid to get hurt; 7. Pain, injury or disability; 8. Weather; 9. Lack of suitable place; 10. Lack of knowledge; 11. Lack of ability; 12. Shame of the body; 13. Need to rest; 14 . Cannot go to the place of practice; 15 . Lack of having fun during practice; 16 . Lack of family support; 17 . Another reason, please describe; and 18. No barrier. Due to low frequency of responses, the barriers from 3 to 17 were grouped into a category named as "other barrier".

\subsection{Television Viewing}

The mean daily hours of television viewing were assessed for weekdays and weekend days by the question: "In a typical weekday/weekend day, how much time do you spend viewing television? Responses were: i. less than $1 \mathrm{~h}$; ii. more than $1 \mathrm{~h}$ but less than $2 \mathrm{~h}$; iii. more than $2 \mathrm{~h}$ but less than $3 \mathrm{~h}$; iv. more than $3 \mathrm{~h}$ but less than $4 \mathrm{~h}$; v. more than $4 \mathrm{~h}$ but less than $5 \mathrm{~h}$; and vi. $5 \mathrm{~h}$ and more. Responses were dichotomously grouped into "less than $2 \mathrm{~h}$ " and " $2 \mathrm{~h}$ and more" according to the previous association of weight gain [25] and health impairment among teachers [15].

\subsection{Socioeconomic Level}

The Brazilian Economic Classification Criteria were used for the assessment of socioeconomic status of the sample [26]. This instrument takes into account the educational level and number of rooms and consumer goods at home, classifying them into economic classes 
(A1, A2, B1, B2, C1, C2, D, and E). The sample was further divided into high (A1, A2, and $\mathrm{B} 1)$, medium (B2 and C1), and low socioeconomic level (C2, D, and E).

\subsection{Smoking, Alcohol Consumption, and Comorbidities}

Smoking habit was self-reported by the question: "Do you currently smoke? Yes or No?" Alcohol consumption was assessed by the question: "Do you habitually consume alcoholic beverages at least once a week? Yes or No?" Regarding comorbidities, participants were asked whether they had a medical diagnosis of hypertension, diabetes, or dyslipidemia. They were also asked about the use of medications for these comorbidities. Positive responses for medical diagnosis or medications were considered as the definition of having a comorbidity.

\subsection{Statistical Analysis}

Descriptive characteristics of the sample were presented as mean and standard deviation for continuous variables and as frequency for categorical variables. The independent sample $t$-test was used to compare continuous variables, while the chi-square test was used for the comparison of proportions. Binary logistic regression was used to analyze the bivariate relationship between obesity and the independent variables. The backward stepwise method was used for assessing multiple relationships, where significant bivariate associations were included in the final model. The 95\% confidence interval and the level of significance at $p<0.05$ were adopted in the analysis performed with the SPSS statistical package, version 24.0 .

\section{Results}

A total of 246 public school teachers were assessed, with an average age of $45.2 \pm 10.4$ years, being composed by $76.0 \%$ women $(n=187)$. The sample presented a mean body mass index of $27.4 \pm 5.4 \mathrm{~kg} / \mathrm{m}^{2}$, mean weekly worked hours of $37.5 \pm 12.2$, and $17.4 \pm 8.6$ years of profession. The prevalence of obesity was $30.1 \%$ in the sample $(n=74)$, with no difference between sex $(27.1 \%$ for men $(n=16)$ vs. $31.0 \%$ for women $(n=58))$, chi-square test $p$-value $=0.247)$. No difference between obese vs. non-obese participants were observed on age $(46.1 \pm 10.4$ vs. $44.9 \pm 10.5, p$-value $=0.395)$, weekly worked hours $(35.9 \pm 11.8$ vs. $38.1 \pm 12.3$, $p$-value $=0.187)$, and years of profession $(18.6 \pm 8.4$ vs. $16.8 \pm 8.7, p$-value $=0.155)$. The characteristics of the sample are presented in Table 1.

Table 1. Characterization of sample $(n=246)$.

\begin{tabular}{cccc}
\hline & \multicolumn{3}{c}{$\mathbf{( \% )}$} \\
\hline Variable & $\begin{array}{c}\text { Overall Sample } \\
(\boldsymbol{n}=\mathbf{2 4 6 )}\end{array}$ & $\begin{array}{c}\text { Men } \\
(\boldsymbol{n}=\mathbf{5 9 )}\end{array}$ & $\begin{array}{c}\text { Women } \\
(\boldsymbol{n}=\mathbf{1 8 7})\end{array}$ \\
\hline Age group * & & \\
$20-29$ & $23(9.3)$ & $9(15.2)$ & $14(7.5)$ \\
$30-39$ & $49(19.9)$ & $20(33.9)$ & $29(15.5)$ \\
$40-49$ & $74(30.2)$ & $11(18.7)$ & $63(33.7)$ \\
$50-59$ & $81(32.9)$ & $14(23.7)$ & $67(35.8)$ \\
60 and more & $19(7.7)$ & $5(8.5)$ & $14(7.5)$ \\
\hline Socioeconomic level * & & $13(22.0)$ & $77(41.2)$ \\
High & $90(36.6)$ & $45(76.3)$ & $103(55.1)$ \\
Medium & $148(60.2)$ & $1(1.7)$ & $7(3.7)$ \\
Low & $8(3.3)$ & & \\
\hline Weekly worked hours * & & $9(15.3)$ & $20(10.7)$ \\
20 h or less & $29(11.8)$ & $31(52.5)$ & $136(72.7)$ \\
21-40 h & $167(67.9)$ & $19(32.2)$ & $31(16.6)$ \\
More than 40 h & $50(20.3)$ & &
\end{tabular}


Table 1. Cont.

\begin{tabular}{|c|c|c|c|}
\hline \multirow[b]{2}{*}{ Variable } & \multicolumn{3}{|c|}{$n(\%)$} \\
\hline & $\begin{array}{l}\text { Overall Sample } \\
\quad(n=246)\end{array}$ & $\begin{array}{c}\text { Men } \\
(n=59)\end{array}$ & $\begin{array}{l}\text { Women } \\
(n=187)\end{array}$ \\
\hline \multicolumn{4}{|l|}{ Years of profession * } \\
\hline 10 years or less & $62(25.2)$ & $26(44.1)$ & $32(17.2)$ \\
\hline $11-20$ years & $97(39.4)$ & $15(25.4)$ & $82(43.9)$ \\
\hline More than 20 years & $87(35.4)$ & $18(30.5)$ & $69(36.9)$ \\
\hline \multicolumn{4}{|l|}{ Sport practice at leisure } \\
\hline Never, rarely & $147(59.7)$ & $32(54.2)$ & $115(61.5)$ \\
\hline Sometimes & $74(30.1)$ & $19(32.2)$ & $55(29.4)$ \\
\hline Often, always & $25(10.2)$ & $8(13.6)$ & $17(9.1)$ \\
\hline \multicolumn{4}{|c|}{$\begin{array}{l}\text { Active commuting by walking or } \\
\text { cycling * }\end{array}$} \\
\hline Never, rarely & $91(37.0)$ & $22(37.3)$ & $69(36.9)$ \\
\hline Sometimes & $108(43.9)$ & $18(30.5)$ & $90(48.1)$ \\
\hline Often, always & $47(19.1)$ & $19(32.2)$ & $28(15.0)$ \\
\hline \multicolumn{4}{|l|}{ TV viewing * } \\
\hline$<2 \mathrm{~h} /$ day & $167(67.9)$ & $32(54.2)$ & $135(72.2)$ \\
\hline$\geq 2 \mathrm{~h} /$ day & $79(32.1)$ & $27(45.8)$ & $52(27.8)$ \\
\hline \multicolumn{4}{|c|}{ Barrier for physical activity * } \\
\hline No barrier & $22(8.9)$ & $6(10.2)$ & $16(8.6)$ \\
\hline $\begin{array}{l}\text { Laziness, tiredness or } \\
\text { discouragement }\end{array}$ & $88(35.8)$ & $23(39.0)$ & $65(34.7)$ \\
\hline Lack of time & $92(37.4)$ & $17(28.8)$ & $75(40.1)$ \\
\hline Other barrier & $44(17.9)$ & $13(22.0)$ & $31(16.6)$ \\
\hline \multicolumn{4}{|l|}{ Smoking * } \\
\hline No & $229(93.1)$ & $51(86.4)$ & $178(95.2)$ \\
\hline Yes & $17(6.9)$ & $8(13.6)$ & $9(4.8)$ \\
\hline \multicolumn{4}{|l|}{ Alcohol consumption * } \\
\hline No & 137 (55.7) & $26(44.1)$ & $111(59.4)$ \\
\hline Yes & $109(44.3)$ & $33(55.9)$ & $76(40.6)$ \\
\hline \multicolumn{4}{|l|}{ Hypertension } \\
\hline No & $196(79.7)$ & $46(78.0)$ & $150(80.2)$ \\
\hline Yes & $50(20.3)$ & $13(22.0)$ & $37(19.8)$ \\
\hline \multicolumn{4}{|l|}{ Diabetes } \\
\hline No & $236(95.9)$ & $57(96.6)$ & $179(95.7)$ \\
\hline Yes & $10(4.1)$ & $2(3.4)$ & $8(4.3)$ \\
\hline \multicolumn{4}{|l|}{ Dyslipidemia } \\
\hline No & $212(86.2)$ & $55(93.2)$ & $157(84.0)$ \\
\hline Yes & $34(13.8)$ & $4(6.8)$ & $30(16.0)$ \\
\hline
\end{tabular}

* Significant difference in proportions according to sex by chi-square test $p$-value $<0.05$.

Table 2 presents the association analysis of obesity with sociodemographic and workrelated factors in public school teachers. No association was observed between obesity and the independent variables of sex, age group, socioeconomic level, hours worked weekly, and years in the profession. 
Table 2. Relationship of obesity with sociodemographic and work-related factors in public school teachers $(n=246)$

\begin{tabular}{|c|c|c|}
\hline & \multicolumn{2}{|c|}{ Obesity (Body Mass Index $\geq 30 \mathrm{~kg} / \mathrm{m}^{2}$ ) } \\
\hline & OR $(95 \% \mathrm{CI})$ & $p$-Value \\
\hline \multicolumn{3}{|l|}{ Sex } \\
\hline Men & Reference & - \\
\hline Women & $1.18(0.61 ; 2.27)$ & 0.614 \\
\hline \multicolumn{3}{|l|}{ Age group } \\
\hline $20-29$ & Reference & - \\
\hline $30-39$ & $2.05(0.59 ; 7.09)$ & 0.259 \\
\hline $40-49$ & $2.25(0.69 ; 7.39)$ & 0.181 \\
\hline $50-59$ & $1.45(0.44 ; 4.81)$ & 0.545 \\
\hline 60 and more & $4.00(0.94 ; 16.9)$ & 0.060 \\
\hline \multicolumn{3}{|l|}{ Socioeconomic level } \\
\hline High & Reference & - \\
\hline Medium & $0.62(0.36 ; 1.10)$ & 0.101 \\
\hline Low & $0.58(0.11 ; 3.02)$ & 0.514 \\
\hline \multicolumn{3}{|c|}{ Hours worked weekly } \\
\hline $20 \mathrm{~h}$ or less & Reference & - \\
\hline $21-40 \mathrm{~h}$ & $0.93(0.39 ; 2.21)$ & 0.867 \\
\hline More than $40 \mathrm{~h}$ & $0.53(0.18 ; 1.52)$ & 0.236 \\
\hline \multicolumn{3}{|c|}{ Years in the profession } \\
\hline 10 years or less & Reference & - \\
\hline $11-20$ years & $1.52(0.74 ; 3.14)$ & 0.253 \\
\hline More than 20 years & $1.40(0.67 ; 2.93)$ & 0.377 \\
\hline
\end{tabular}

OR: Odds ratio; CI: Confidence interval.

The association of obesity with lifestyle habits and comorbidities is presented in Table 3. Public school teachers who reported frequently practicing sports were $78 \%$ less likely to have obesity than those who reported never/rarely practicing sports $(\mathrm{OR}=0.22$, $p=0.047)$. Participants who reported actively commuting sometimes or frequently were, respectively, $46 \%(\mathrm{OR}=0.54, p=0.047)$ and $74 \%(\mathrm{OR}=0.26, p=0.004)$ less likely to have obesity. Regarding TV viewing time, teachers who reported 2 or more daily hours of TV viewing were twice as likely to have obesity when compared to those with less than $2 \mathrm{~h}(\mathrm{OR}=2.07, p=0.012)$. When we analyzed the barriers to practicing physical activity, teachers who reported laziness, tiredness, or discouragement as the main barrier to physical activity were more likely to have obesity than those who reported no barrier ( $\mathrm{OR}=6.79$, $p=0.014)$. Obesity also presented an association with comorbidities, where teachers who reported to have hypertension $(\mathrm{OR}=2.66, p=0.003)$ and diabetes $(\mathrm{OR}=5.82, p=0.013)$ were more likely to have obesity than those without these diseases.

Table 3. Relationship of obesity with lifestyle habits and comorbidities in public school teachers $(n=246)$.

\begin{tabular}{lcc}
\hline & \multicolumn{2}{c}{ Obesity (Body Mass Index $\left.\geq \mathbf{3 0 ~} \mathbf{~ k g} / \mathbf{m}^{2}\right)$} \\
\cline { 2 - 3 } & OR $\mathbf{( 9 5 \% ~ C I )}$ & $p$-Value \\
\hline Sport practice & & - \\
Never, rarely & Reference $(1.00)$ & 0.724 \\
Sometimes & $0.89(0.48 ; 1.66)$ & 0.047 \\
Often, always & $0.22(0.05 ; 0.98)$ & \\
\hline
\end{tabular}


Table 3. Cont.

\begin{tabular}{|c|c|c|}
\hline & \multicolumn{2}{|c|}{ Obesity (Body Mass Index $\geq 30 \mathrm{~kg} / \mathrm{m}^{2}$} \\
\hline & OR $(95 \% \mathrm{CI})$ & $p$-Value \\
\hline \multicolumn{3}{|l|}{ Active commuting by walking or cycling } \\
\hline Never, rarely & Reference (1.00) & - \\
\hline Sometimes & $0.54(0.30 ; 0.99)$ & 0.047 \\
\hline Often, always & $0.26(0.10 ; 0.64)$ & 0.004 \\
\hline \multicolumn{3}{|l|}{ TV viewing } \\
\hline$<2$ h/day & Reference & - \\
\hline$\geq 2$ h/day & $2.07(1.17 ; 3.66)$ & 0.012 \\
\hline \multicolumn{3}{|l|}{ Barrier to physical activity } \\
\hline No barrier & Reference & - \\
\hline Laziness, tiredness, or discouragement & $6.79(1.48 ; 31.03)$ & 0.014 \\
\hline Lack of time & $3.11(0.67 ; 14.47)$ & 0.146 \\
\hline Other barrier & $3.68(0.74 ; 18.25)$ & 0.111 \\
\hline \multicolumn{3}{|l|}{ Smoking } \\
\hline No & Reference & - \\
\hline Yes & $0.29(0.06 ; 1.30)$ & 0.105 \\
\hline \multicolumn{3}{|l|}{ Alcohol consumption } \\
\hline No & Reference & - \\
\hline Yes & $1.31(0.75 ; 2.26)$ & 0.341 \\
\hline \multicolumn{3}{|l|}{ Hypertension } \\
\hline No & Reference & - \\
\hline Yes & $2.66(1.40 ; 5.05)$ & 0.003 \\
\hline \multicolumn{3}{|l|}{ Diabetes } \\
\hline No & Reference & - \\
\hline Yes & $5.82(1.46 ; 23.16)$ & 0.013 \\
\hline \multicolumn{3}{|l|}{ Dyslipidemia } \\
\hline No & Reference & - \\
\hline Yes & $1.51(0.71 ; 3.21)$ & 0.282 \\
\hline
\end{tabular}

OR: Odds ratio; CI: Confidence interval.

A multiple binary regression analysis with a backward method was used to identify the main factors associated with obesity among previous significant bivariate associations -Table 4. After multiple steps of backward analysis, frequent active commuting ( $\mathrm{OR}=0.22$, $p=0.007)$, TV viewing $(\mathrm{OR}=2.10, p=0.025)$, and hypertension $(\mathrm{OR}=2.62, p=0.010)$ remained significantly associated with obesity, while diabetes became marginally associated $(\mathrm{OR}=4.14, p=0.075)$.

Table 4. Backward multiple binary logistic regression between obesity and bivariate-associated factors in public school teachers $(n=246)$.

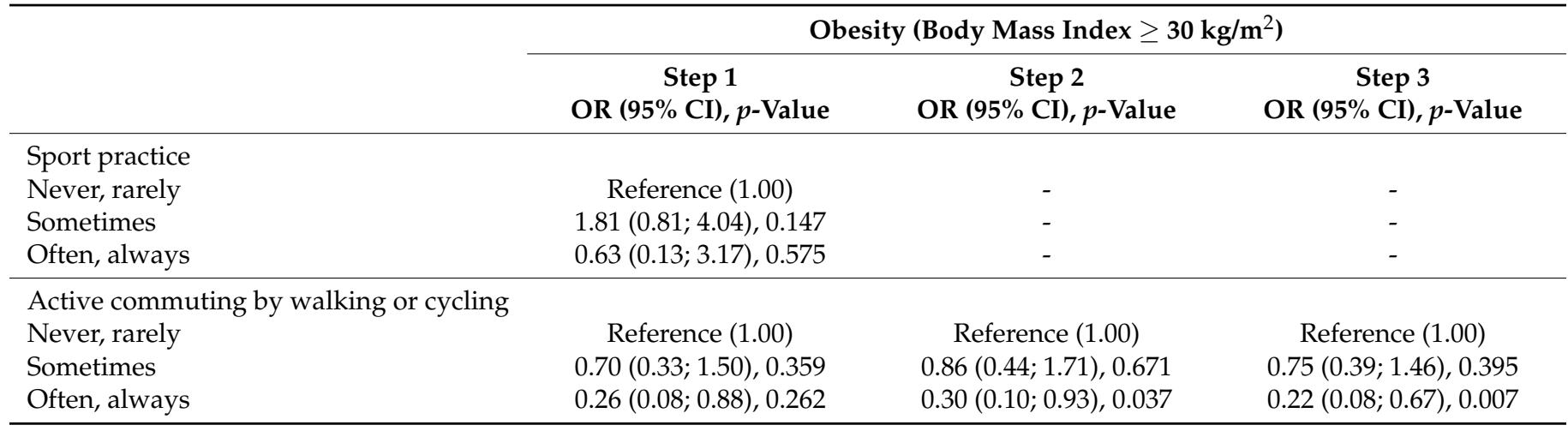


Table 4. Cont.

\begin{tabular}{|c|c|c|c|}
\hline & \multicolumn{3}{|c|}{ Obesity (Body Mass Index $\geq 30 \mathrm{~kg} / \mathrm{m}^{2}$ ) } \\
\hline & $\begin{array}{c}\text { Step } 1 \\
\text { OR (95\% CI), } p \text {-Value }\end{array}$ & $\begin{array}{c}\text { Step } 2 \\
\text { OR (95\% CI), } p \text {-Value }\end{array}$ & $\begin{array}{c}\text { Step } 3 \\
\text { OR (95\% CI), } p \text {-Value }\end{array}$ \\
\hline $\begin{array}{l}\text { TV viewing } \\
<2 \mathrm{~h} / \text { day } \\
\geq 2 \mathrm{~h} / \text { day }\end{array}$ & $\begin{array}{c}\text { Reference }(1.00) \\
1.75(0.89 ; 3.44), 0.104\end{array}$ & $\begin{array}{c}\text { Reference }(1.00) \\
1.85(0.95 ; 3.60), 0.071\end{array}$ & $\begin{array}{c}\text { Reference }(1.00) \\
2.10(1.10 ; 4.02), 0.025\end{array}$ \\
\hline $\begin{array}{l}\text { Barrier to physical activity } \\
\text { No barrier } \\
\text { Laziness, tiredness, or discouragement } \\
\text { Lack of time } \\
\text { Other barrier }\end{array}$ & $\begin{array}{c}\text { Reference }(1.00) \\
4.50(0.78 ; 26.04), 0.093 \\
2.46(0.43 ; 14.22), 0.315 \\
2.94(0.48 ; 17.98), 0.243\end{array}$ & $\begin{array}{c}\text { Reference }(1.00) \\
4.66(0.82 ; 26.62), 0.083 \\
2.57(0.45 ; 14.69), 0.288 \\
3.09(0.51 ; 18.61), 0.218\end{array}$ & $\begin{array}{l}- \\
- \\
- \\
-\end{array}$ \\
\hline $\begin{array}{l}\text { Hypertension } \\
\text { No } \\
\text { Yes }\end{array}$ & $\begin{array}{c}\text { Reference }(1.00) \\
2.94(1.35 ; 6.41), 0.007\end{array}$ & $\begin{array}{c}\text { Reference }(1.00) \\
2.79(1.30 ; 5.96), 0.008\end{array}$ & $\begin{array}{c}\text { Reference }(1.00) \\
2.62(1.25 ; 5.49), 0.010\end{array}$ \\
\hline $\begin{array}{l}\text { Diabetes } \\
\text { No } \\
\text { Yes }\end{array}$ & $\begin{array}{c}\text { Reference }(1.00) \\
5.57(0.95 ; 32.67), 0.057\end{array}$ & $\begin{array}{c}\text { Reference }(1.00) \\
5.06(0.92 ; 27.88), 0.063\end{array}$ & $\begin{array}{c}\text { Reference (1.00) } \\
4.14(0.87 ; 19.74), 0.075\end{array}$ \\
\hline
\end{tabular}

\section{Discussion}

The main study findings showed a prevalence of obesity of $30.1 \%$ in the sample. Obesity was associated with lifestyle and comorbidities among public school teachers, while no association was observed with sociodemographic and work-related factors. In the multiple analysis, obesity remained negatively associated with frequent active commuting, whereas it was positively associated with elevated TV viewing and hypertension.

The prevalence of obesity in the present study was more than twice as high as the global prevalence in the adult population (30.1 vs. $13.0 \%$ ) and this warming finding will need to be further analyzed for determinants investigation. This elevated prevalence of obesity in the present study was in line with previous findings from Zubery et al. [27], where the prevalence of obesity among 305 Tanzanian health-workers, teachers and bankers reached $37.8 \%$, and teachers presented a prevalence of overweight/obesity of $62.6 \%$, similarly of present study ( $\sim 60 \%$ when considering overweight/obesity). A study from Lizana et al. [28] involving 70 Chilean rural teachers also reported an elevated prevalence of obesity $(25.7 \%)$, but lower than present study findings. It is important to highlight that this elevated prevalence of obesity may also have been related to the age of sample in the present study, since the obesity prevalence increases with advancing of age, reaching its peak in age groups from 40 to 60 years [29], which was the most prevalent age-groups in our sample $(63.1 \%)$.

The higher prevalence of obesity among teachers may be related to high levels of sedentary behavior at leisure [30], and the association of prolonged time in screen-based sedentary behaviors with unhealthy eating habits [31], which may contribute to a high positive caloric imbalance. In addition, teachers reported several job stressors, which affect sleep quality [32] and teachers with poor sleep presented higher body mass indices than those with a good quality of sleep [33].

Teachers who never or rarely practice sports at leisure or active commuting were more likely to have obesity. It has been observed that $50 \%$ of teachers have low levels of physical activity [34]. The low engagement in physical activities of higher energy expenditure may contribute to a positive caloric imbalance, leading to weight gain and, consequently, obesity. Sports practice is the most intense domain of physical activity [35], while frequent active commuting may substantially increase daily expenditure, contributing to weight management [36]. Nevertheless, the present study observed that teachers who reported a perceived barrier to physical activity (laziness, tiredness, or discouragement) were more likely to have obesity than those who reported no barrier to physical activity. Teachers 
have specific environmental and psychological exposures that may affect their jobs and people involved with their occupation [12], resulting in excessive mental stress and may compromise their wellbeing and motivation for engagement in physical activity.

Screen time was another factor associated with obesity in the present study, where teachers who spent 2 or more hours at TV viewing were more likely to have obesity. Screen-based sedentary behavior has been associated with obesity in adults, especially TV viewing [37]. The time spent in front of screen devices such as television generally is spent in a seated or reclined position, and resulted in a low-energy expenditure behavior [38]. In addition, the entertainment content on TV may be accompanied by broadcasted advertisements of unhealthy foods, which may trigger snacking habits [39] and lead to unhealthy snacking choices with high caloric density [40], elevating daily caloric intake and contributing to weigh gain.

Regarding the comorbidities assessed in the present study, public school teachers with obesity showed an association with hypertension and diabetes. This finding corroborates the evidence in the literature where the incidence of comorbidities related with obesity has been reported, especially regarding diabetes and cardiovascular diseases [41]. Adipose tissue has been considered as an endocrine organ that releases inflammatory cytokines [42], contributing to increased arterial stiffness [43], kidney function impairment [44], and the raising of sympathetic modulation by impairment of the cholinergic anti-inflammatory pathway [45]. These mechanisms together contribute substantially to increasing blood pressure levels.

Regarding the association of obesity with diabetes, previous findings reported that the prevalence of diabetes increases with the increase of weight class, being more than 5 times higher among obese than normal-weight adults $[46,47]$. Obese individuals presented higher amounts of several substances that lead to insulin resistance, such as nonesterified fatty acids, glycerol, hormones, and inflammatory markers, which may cause an impairment in blood glucose control and consequently leads to diabetes onset [48]. In addition, diabetes onset has been associated with a pro-inflammatory profile [49], which may substantially contribute to obesity due to adipocytokine release and consequent chronic metabolic disorders [50].

The multiple analysis showed that active commuting, TV viewing, and hypertension remained associated with obesity independently of each other. Recent strategies for physical activity promotion have also been accompanied by the limitation of screen-based sedentary time [51]. Both physical activity and sedentary behavior were important factors for weight management and hypertension control [52], and also need to be emphasized among public school teachers. TV viewing is an important health problem for coping, since it has been associated with increased all-cause mortality in Brazilian adults independently of physical activity [53].

The present study has important limitations. First, the quality of diet was not assessed, which precludes inference of the mediator effect of unhealthy eating habits in the relationship between obesity and independent variables. Second, the cross-sectional design precludes the inference of whether adiposity could be a cause or a consequence of lifestyle habits and comorbidities. Third, self-reported information on lifestyle habits was susceptible to biases of memory and classification, and the definition of obesity by body mass index could not reflect obesity in elevated muscle-mass subjects and those with normal with but low muscle mass and higher adiposity as well. As strengths of study, the sampling process covered all of the teachers from the public state schools in the city, and the multiple analysis provided novel information about the factors associated with obesity in this specific population.

In conclusion, obesity was negatively associated with frequent engagement in active commuting and positively associated with elevated TV-viewing time and hypertension in public school teachers. Strategies for facing obesity among teachers need to be focused on improving physical activity levels from different domains, especially active commuting, as 
well as limiting the daily amount of TV viewing. However, the analysis of longitudinal data and dose-response investigation are still needed.

Author Contributions: Conceptualization, W.R.T., F.C.S.G., L.D.D. and D.G.D.C.; methodology, D.G.D.C., F.C.S.G. and L.D.D.; formal analysis, W.R.T.; resources, D.G.D.C. and J.M.; data curation, W.R.T., F.C.S.G., L.D.D. and J.M.S.; writing - original draft preparation, W.R.T. and F.C.S.G.; writing—review and editing, D.G.D.C. and J.M.; project administration, D.G.D.C. All authors have read and agreed to the published version of the manuscript.

Funding: This research was funded in part by COORDENAÇÃO DE APERFEIÇOAMENTO DE PESSOAL DE NÍVEL SUPERIOR-CAPES, Brazil, Finance code 001. J.M. received funding by FCT: UIDB/00617/2020 and LA/P/0064/2020.

Institutional Review Board Statement: The study was conducted according to the guidelines of the Declaration of Helsinki, and approved by the Research Ethics Committee of SAO PAULO STATE UNIVERSITY (protocol code 72191717.9.0000.5402, approved on 23 June 2015).

Informed Consent Statement: Informed consent was obtained from all subjects involved in the study, authorizing the research and dissemination of results.

Data Availability Statement: The data presented in this study are available upon reasoned request to the corresponding author. The data is not publicly available due to the preservation of personal information of participants.

Acknowledgments: The authors thank for the State Department of Education in the city of Presidente Prudente for the authorization to carry out the research, the School Managers of enrolled schools, and for the teachers who agreed to participate in this research.

Conflicts of Interest: The authors declare no conflict of interest.

\section{References}

1. Swinburn, B.A.; Sacks, G.; Hall, K.D.; McPherson, K.; Finegood, D.T.; Moodie, M.L.; Gortmaker, S.L. The global obesity pandemic: Shaped by global drivers and local environments. Lancet 2011, 378, 804-814. [CrossRef]

2. World Health Organization. Obesity and Overweight. Available online: https://www.who.int/news-room/fact-sheets/detail/ obesity-and-overweight (accessed on 25 November 2021).

3. Ramón-Arbués, E.; Martínez-Abadía, B.; Gracia-Tabuenca, T.; Yuste-Gran, C.; Pellicer-García, B.; Juárez-Vela, R.; Guerrero-Portillo, S.; Sáez-Guinoa, M. Prevalence of overweight/obesity and its association with diabetes, hypertension, dyslipidemia and metabolic syndrome: A cross-sectional study of a sample of workers in Aragón, Spain. Nutr. Hosp. 2018, 36, 51-59. [CrossRef]

4. De Pergola, G.; Silvestris, F. Obesity as a Major Risk Factor for Cancer. J. Obes. 2013, 2013, 291546. [CrossRef] [PubMed]

5. Brumpton, B.; Langhammer, A.; Romundstad, P.R.; Chen, Y.; Mai, X.-M. The associations of anxiety and depression symptoms with weight change and incident obesity: The HUNT Study. Int. J. Obes. 2012, 37, 1268-1274. [CrossRef]

6. Weinberger, N.-A.; Kersting, A.; Riedel-Heller, S.G.; Luck-Sikorski, C. Body Dissatisfaction in Individuals with Obesity Compared to Normal-Weight Individuals: A Systematic Review and Meta-Analysis. Obes. Facts 2016, 9, 424-441. [CrossRef]

7. Flegal, K.M.; Kit, B.K.; Orpana, H.; Graubard, B.I. Association of All-Cause Mortality with Overweight and Obesity Using Standard Body Mass Index Categories: A systematic review and meta-analysis. JAMA 2013, 309, 71-82. [CrossRef]

8. Panuganti, K.K.; Nguyen, M.; Kshirsagar, R.K. Obesity. In StatPearls [Internet]; StatPearls Publishing: Treasure Island, FL, USA, 2021.

9. Cornier, M.A.; Despres, J.P.; Davis, N.; Grossniklaus, D.A.; Klein, S.; Lamarche, B.; Lopez-Jimenez, F.; Rao, G.; St-Onge, M.P.; Towfighi, A.; et al. Assessing adiposity: A scientific statement from the American Heart Association. Circulation 2011, 124, 1996-2019. [CrossRef]

10. Hill, J.O.; Wyatt, H.R.; Peters, J.C. Energy Balance and Obesity. Circulation 2012, 126, 126-132. [CrossRef]

11. Romieu, I.; Dossus, L.; Barquera, S.; Blottière, H.M.; Franks, P.W.; Gunter, M.; Hwalla, N.; Hursting, S.D.; Leitzmann, M.; Margetts, B.; et al. Energy balance and obesity: What are the main drivers? Cancer Causes Control 2017, 28, 247-258. [CrossRef]

12. Scheuch, K.; Haufe, E.; Seibt, R. Teachers' Health. Dtsch. Arztebl. Int. 2015, 112, 347-356. [CrossRef]

13. Bannai, A.; Ukawa, S.; Tamakoshi, A. Long working hours and psychological distress among school teachers in Japan. J. Occup. Health 2015, 57, 20-27. [CrossRef] [PubMed]

14. Pirzadeh, A.; Sharifirad, G.; Kamran, A. Healthy lifestyle in teachers. J. Educ. Health Promot. 2012, 1, 46. [CrossRef] [PubMed]

15. de Souza, S.C.S.; Campanini, M.Z.; de Andrade, S.M.; González, A.D.; de Melo, J.M.; Mesas, A.E. Watching television for more than two hours increases the likelihood of reporting poor sleep quality among Brazilian schoolteachers. Physiol. Behav. 2017, 179, 105-109. [CrossRef] 
16. Committee on Physical Activity and Physical Education in the School Environment; Food and Nutrition Board; Institute of Medicine. 6, Approaches to Physical Activity in Schools. In Educating the Student Body: Taking Physical Activity and Physical Education to School; Kohl, H.W., III, Cook, H.D., Eds.; National Academies Press (US): Washington, DC, USA, 2013. Available online: https:/ / www.ncbi.nlm.nih.gov/books/NBK201495/ (accessed on 7 November 2021).

17. Rosales-Ricardo, Y.; Orozco, D.; Yaulema, L.; Parreño, A.; Caiza, V.; Barragán, V. Physical activity and health in teachers. A review. Apunts Med. Esport 2017, 52, 159-166. [CrossRef]

18. Agranonik, M.; Hirakata, V.N. Sample size calculation: Proportions. Rev. HCPA 2011, 31, 382-388.

19. WHO-World Health Organization. Physical status: The use and interpretation of anthropometry. Report of a WHO Expert Committee. World Health Organ. Tech. Rep. Ser. 1995, 854, 1-452.

20. Baecke, J.A.; Burema, J.; Frijters, J.E. A short questionnaire for the measurement of habitual physical activity in epidemiological studies. Am. J. Clin. Nutr. 1982, 36, 936-942. [CrossRef]

21. Philippaerts, R.M.; Westerterp, K.R.; Lefevre, J. Doubly Labeled Water Validation of three Physical Activity Questionnaires. Int. J. Sports Med. 1999, 20, 284-289. [CrossRef]

22. Philippaerts, R.M.; Westerterp, K.R.; Lefevre, J. Comparison of Two Questionnaires with a Tri-Axial Accelerometer to Assess Physical Activity Patterns. Int. J. Sports Med. 2001, 22, 34-39. [CrossRef]

23. Florindo, A.A.; de Oliveira Latorre, M.d.R.D. Validation and reliability of the Baecke questionnaire for the evaluation of habitual physical activity in adult men. Rev. Bras. Med. Esporte 2003, 9, 129-135. [CrossRef]

24. Justine, M.; Azizan, A.; Hassan, V.; Salleh, Z.; Manaf, H. Barriers to participation in physical activity and exercise among middle-aged and elderly individuals. Singap. Med. J. 2013, 54, 581-586. [CrossRef] [PubMed]

25. Martínez-Moyá, M.; Navarrete-Muñoz, E.M.; de la Hera, M.G.; Giménez-Monzo, D.; González-Palacios, S.; Valera-Gran, D.; Sempere-Orts, M.; Vioque, J. Asociación entre horas de televisión, actividad física, horas de sueño y exceso de peso en población adulta joven. Gac. Sanit. 2014, 28, 203-208. [CrossRef] [PubMed]

26. Instituto Brasileiro de Opinião Pública e Estatística. Levantamento Sócio Econômico-2009-IBOPE. Rio de Janeiro. Available online: www.abep.org/novo/CMS/Utils/FileGenerate.ashx?id=46 (accessed on 13 October 2021).

27. Zubery, D.; Kimiywe, J.; Martin, H.D. Prevalence of Overweight and Obesity, and Its Associated Factors among Health-care Workers, Teachers, and Bankers in Arusha City, Tanzania. Diabetes Metab. Syndr. Obes. 2021, 14, 455-465. [PubMed]

28. Lizana, P.A.; Aballay, J.; Vicente-Rodríguez, G.; Gómez-Bruton, A. Low interest in physical activity and higher rates of obesity among rural teachers. Work 2020, 67, 1015-1022. [CrossRef]

29. Low, S.; Chin, M.C.; Deurenberg-Yap, M. Review on epidemic of obesity. Ann. Acad. Med. Singap. 2009, $38,57$.

30. Delfino, L.D.; Tebar, W.; Gil Tebar, F.C.S.; De Souza, J.M.; Romanzini, M.; Fernandes, R.A.; Christofaro, D.G.D. Association between sedentary behavior, obesity and hypertension in public school teachers. Ind. Health 2020, 58, 345-353. [CrossRef]

31. Delfino, L.D.; Tebar, W.R.; Gil, F.C.; De Souza, J.M.; Romanzini, M.; Fernandes, R.A.; Christofaro, D.G.D. Association of sedentary behaviour patterns with dietary and lifestyle habits among public school teachers: A cross-sectional study. BMJ Open 2020, 10, e034322. [CrossRef]

32. Kottwitz, M.U.; Gerhardt, C.; Pereira, D.; Iseli, L.; Elfering, A. Teacher's sleep quality: Linked to social job characteristics? Ind. Health 2018, 56, 53-61. [CrossRef]

33. de Souza, J.M.; Pinto, R.Z.D.A.; Tebar, W.R.; Gil, F.C.; Delfino, L.D.; Morelhão, P.K.; da Silva, C.C.; Oliveira, C.B.; Christofaro, D.G. Association of musculoskeletal pain with poor sleep quality in public school teachers. Work 2020, 65, 599-606. [CrossRef]

34. Brito, W.F.; dos Santos, C.L.; Marcolongo, A.D.A.; Campos, M.D.; Bocalini, D.S.; Antonio, E.L.; Junior, J.A.S.; Tucci, P.; Serra, A. Nível de atividade física em professores da rede estadual de ensino. Rev. Saúde Pública 2012, 46, 104-109. [CrossRef]

35. MacIntosh, B.R.; Murias, J.M.; Keir, D.A.; Weir, J.M. What Is Moderate to Vigorous Exercise Intensity? Front. Physiol. 2021, 12, 1481. [CrossRef]

36. Costa, S.; Ogilvie, D.; Dalton, A.; Westgate, K.; Brage, S.; Panter, J. Quantifying the physical activity energy expenditure of commuters using a combination of global positioning system and combined heart rate and movement sensors. Prev. Med. 2015, 81, 339-344. [CrossRef]

37. Heinonen, I.; Helajärvi, H.; Pahkala, K.; Heinonen, O.J.; Hirvensalo, M.; Pälve, K.; Tammelin, T.; Yang, X.; Juonala, M.; Mikkilä, V.; et al. Sedentary behaviours and obesity in adults: The Cardiovascular Risk in Young Finns Study. BMJ Open 2013,3 , e002901. [CrossRef]

38. Healy, G.N.; Clark, B.K.; Winkler, E.A.; Gardiner, P.A.; Brown, W.J.; Matthews, C.E. Measurement of Adults' Sedentary Time in Population-Based Studies. Am. J. Prev. Med. 2011, 41, 216-227. [CrossRef]

39. Harris, J.L.; Bargh, J.A.; Brownell, K.D. Priming effects of television food advertising on eating behavior. Health Psychol. 2009, 28, 404-413. [CrossRef]

40. O'Connor, L.; Brage, S.; Griffin, S.J.; Wareham, N.J.; Forouhi, N.G. The cross-sectional association between snacking behaviour and measures of adiposity: The Fenland Study, UK. Br. J. Nutr. 2015, 114, 1286-1293. [CrossRef]

41. Guh, D.P.; Zhang, W.; Bansback, N.; Amarsi, Z.; Birmingham, C.L.; Anis, A.H. The incidence of co-morbidities related to obesity and overweight: A systematic review and meta-analysis. BMC Public Health 2009, 9, 88. [CrossRef]

42. Lyon, C.J.; Law, R.E.; Hsueh, W.A. Minireview: Adiposity, Inflammation, and Atherogenesis. Endocrinology 2003, 144, 2195-2200. [CrossRef] 
43. McGill, H.C.; Mcmahan, C.A.; Herderick, E.E.; Zieske, A.W.; Malcom, G.T.; Tracy, R.E.; Strong, J.P. Obesity Accelerates the Progression of Coronary Atherosclerosis in Young Men. Circulation 2002, 105, 2712-2718. [CrossRef]

44. Martin-Taboada, M.; Vila-Bedmar, R.; Medina-Gómez, G. From Obesity to Chronic Kidney Disease: How Can Adipose Tissue Affect Renal Function? Nephron 2021, 145, 609-613. [CrossRef]

45. Williams, D.P.; Koenig, J.; Carnevali, L.; Sgoifo, A.; Jarczok, M.N.; Sternberg, E.M.; Thayer, J.F. Heart rate variability and inflammation: A meta-analysis of human studies. Brain Behav. Immun. 2019, 80, 219-226. [CrossRef]

46. Nguyen, N.T.; Nguyen, X.-M.T.; Lane, J.; Wang, P. Relationship between Obesity and Diabetes in a US Adult Population: Findings from the National Health and Nutrition Examination Survey, 1999-2006. Obes. Surg. 2010, 21, 351-355. [CrossRef]

47. Wilding, J.P.H. The importance of weight management in type 2 diabetes mellitus. Int. J. Clin. Pract. 2014, 68, 682-691. [CrossRef]

48. Algoblan, A.; Alalfi, M.; Khan, M. Mechanism linking diabetes mellitus and obesity. Diabetes Metab. Syndr. Obes. Targets Ther. 2014, 7, 587-591. [CrossRef]

49. Lazar, M.A. How Obesity Causes Diabetes: Not a Tall Tale. Science 2005, 307, 373-375. [CrossRef]

50. Zorena, K.; Jachimowicz-Duda, O.; Ślęzak, D.; Robakowska, M.; Mrugacz, M. Adipokines and Obesity. Potential Link to Metabolic Disorders and Chronic Complications. Int. J. Mol. Sci. 2020, 21, 3570. [CrossRef]

51. Bull, F.C.; Al-Ansari, S.S.; Biddle, S.; Borodulin, K.; Buman, M.; Cardon, G.; Carty, C.; Chaput, J.-P.; Chastin, S.; Chou, R.; et al. World Health Organization 2020 guidelines on physical activity and sedentary behaviour. Br. J. Sports Med. 2020, 54, $1451-1462$. [CrossRef]

52. Bakker, E.A.; Sui, X.; Brellenthin, A.G.; Lee, D.-C. Physical activity and fitness for the prevention of hypertension. Curr. Opin. Cardiol. 2018, 33, 394-401. [CrossRef]

53. Turi, B.C.; Monteiro, H.L.; Lemes, I.R.; Codogno, J.S.; Lynch, K.R.; Mesquita, C.A.A.; Fernandes, R. TV viewing time is associated with increased all-cause mortality in Brazilian adults independent of physical activity. Scand. J. Med. Sci. Sports 2017, 28, 596-603. [CrossRef] 